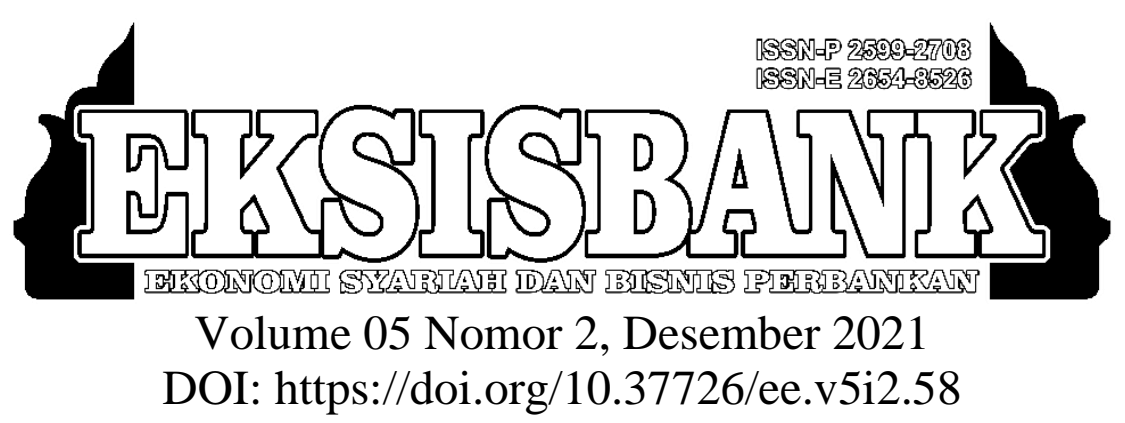

\title{
Pengaruh Penerapan Akad Isthisna Terhadap Minat Beli Masyarakat Di Perumahan Nakhil Garden Pawarengan Cikampek Barat
}

\author{
Dian Rosdiana $^{1}$, Ahmad Ali Sopian², Jalaludin ${ }^{3}$ \\ ${ }^{1,2,3}$ Sekolah Tinggi Ilmu Ekonomi Syariah (STIES) Indonesia Purwakarta \\ 1dianrosdianna@gmail.com \\ 2 ahmadalisopian@sties-purwakarta.ac.id \\ 3jalaludin@sties-purwakarta.ac.id
}

\begin{abstract}
ABSTRAK
Kebutuhan rumah hunian menjadi kebutuhan mendasar setelah kebutuhan sandang dan pangan. Perumahan Nakhil Garden Pawarengan Cikampek menjadi salah satu developer properti syari'ah yang menyediakan produk hunian siap bangun, dengan menggunakan sistem syari'ah non Bank dalam menjalankan bisnisnya, yaitu mengunakan akad isthisna atau pemesanan terlebih dahulu tanpa ada sentuhan riba. Tujuan dari penelitian ini adalah untuk mengetahui pengaruh penerapan akad Istishna terhadap minat beli masyarakat pada perumahan Nakhil Garden Pawarengan Cikampek, dan untuk mengetahui seberapa besar pengaruh Penerapan akad Istishna terhadap minat masyarakat untuk membeli perumahan Nakhil garden Pawarengan Cikampek. Penelitian ini menggunakan metode Kuantitatif, pengumpulan data dilakukan dengan cara observasi, wawancara, menyebarkan data responden kuisioner dan dokumentasi. Populasi dalam penelitian ini adalah konsumen yang membeli dan berminat membeli perumahan tersebut dengan jumlah sample sebanyak 40 orang. Teknik pengambilan sampel yaitu probability sampling mengunakan simple random sampling. Jenis data yang digunakan adalah data primer dengan metode pengumpulan data kuisioner. Kemudian teknik analisis menggunakan analisis data regresi linear sederhana. Hasil dari penelitian ini menunjukkan bahwa, akad isthisna yang diterapkan oleh perumahan Nakhil Garden tidak memiliki pengaruh terhadap minat beli masyarakat, hal ini dapat dilihat dari hasil uji regresi yaitu nilai koefisien determinasi ( $\mathrm{R}$ Square) yang dihasilkan adalah sebesar 0.187 dari nilai korelasi / hubungan (R) sebesar 0.432. sehingga dapat diartikan bahwa Penerapan Akad Istishna memberikan pengaruh terhadap Minat Beli pada perumahan Nakhil Garden Pawarengan sebesar $18,7 \%$, sisanya $81,3 \%$ dipengaruhi oleh faktor lain yang tidak di teliti pada penelitian ini.
\end{abstract}

Kata Kunci : Akad Isthisna, Minat Beli, Perumahan Nakhil Garden.

EKSISBANK (Ekonomi Syariah dan Bisnis Perbankan), Volume 5, Nomor 2, Desember 2021 


\begin{abstract}
The need for housing is a basic need after the need for clothing and food. Housing Nakhil Garden Pawarengan Cikampek is one of the sharia property developers that provides ready-tobuild residential products, using a non-bank sharia system in running their business, namely using an isthisna contract or advance reservation without any touch of usury. The purpose of this study was to determine the effect of the application of the Istishna contract on people's buying interest in the Nakhil Garden Pawarengan Cikampek housing, and to determine how much influence the application of the Istishna contract had on the public's interest in buying housing at Nakhil Garden Pawarengan Cikampek. This study uses quantitative methods, data collection is done by means of observation, interviews, distributing questionnaires and documentation respondent data. The population in this study are consumers who buy and are interested in buying housing with a sample of 40 people. The sampling technique is probability sampling using simple random sampling. The type of data used is primary data with a questionnaire data collection method. Then the analysis technique using simple linear regression data analysis. The results of this study indicate that the isthisna contract applied by Nakhil Garden housing has no effect on people's buying interest, this can be seen from the results of the regression test, namely the value of the coefficient of determination ( $R$ Square) generated is 0.187 from the correlation / relationship value ( $\mathrm{R})$ of 0.432 . so that it can be interpreted that the application of the Istishna contract has an influence on buying interest in Nakhil Garden Pawarengan housing by $18.7 \%$, the remaining $81.3 \%$ is influenced by other factors not examined in this study.
\end{abstract}

Keywords: Isthisna Contract, Buying Interest, Nakhil Garden Housing.

\section{PENDAhuluan}

Hukum Indonesia memberikan perlindungan terhadap hak warga Negara untuk memiliki property. Hak atas kepemilikan properti memiliki keterkaitan dengan untuk bertempat tinggal, adapun hukumnya tercantum dalam UUD 1945 khususnya dalam pasal 28e ayat 1 yang berbunyi "setiap orang bebas memeluk agama dan beribadat menurut agamanya, memilih pendidikan dan pengajaran, memilih pekerjaan, memilih kewarganegaraan, memilih tempat tinggal diwilayah Negara dan meninggalkannya serta berhak kembali" (Peace 2017).

Properti diartikan sebagai harta berupa tanah dan bangunan serta sarana dan prasarana yang merupakan bagian yang tidak terpisahkan dari tanah dan/atau bangunan yang dimaksudkan. Property merupakan salah satu kebutuhan dasar manusia (Wijaya and Ananta 2017).

Secara singkat, properti merupakan tanah milik dan bangunan. Ada pula yang mendefinisikan arti properti sebagai hak untuk memiliki sebidang tanah dan memanfaatkan apa saja yang ada di atasnya. Dikalangan masyarakat umum, istilah properti lebih familiar dengan pengertian suatu hunian seperti rumah, Ruko, dan apartemen (Wardhani and others 2015).

Perumahan Nakhil Garden Pawarengan adalah perumahan yang mengadopsi sistem syariah (akad Istishna), perumahan ini menawarkan sistem penjualan tanpa riba, tanpa adanya pihak ke tiga yaitu Bank, tanpa denda dan sita, sistem penjualan yang ditawarkan adalah hanya meliputi dua pihak yakni developer dan pembeli, pembayaran dapat dikredit langsung kepada developer dengan jangka waktu tertentu yang telah

EKSISBANK (Ekonomi Syariah dan Bisnis Perbankan), Volume 5, Nomor 2, Desember 2021 
disepakati dan mengunakan akan Istishna, akad Istishna disini secara pembayaran hanya melibatkan 2 pihak akan tetapi secara ketersediaan produk melibatkan 3 pihak yaitu pihak Pembeli, Nakhil Garden dan pihak kontraktor (kontrkator diberikan kuasa untuk membuat rumah dengan bahan material telah tersedia dari pihak Nakhil Garden.

Bisnis dengan basis syariah akan membawa wirausaha muslim kepada kesejahteraan dunia dan akherat dengan selalu memenuhi standar etika perilaku bisnis, yaitu: takwa, kebaikan, ramah dan amanah (Hasan 2009), Sebagaimana yang tercantum dalam Al Quran, Hadist dan Ijma ulama.

Firman Allah SWT salah satunya telah jelas menyebutkan larangan bertransaksi yang mengandung riba dalam al-Quran surat alBaqarah ayat 275:

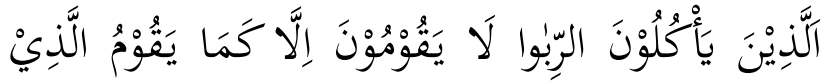

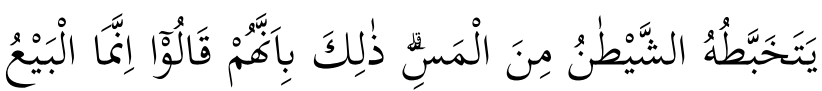

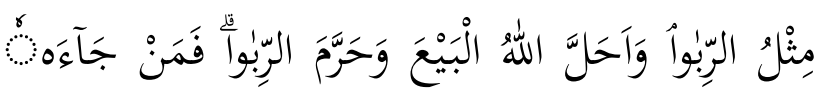

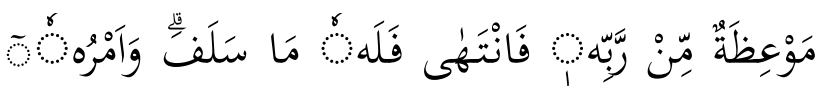

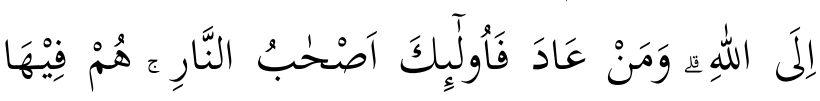

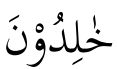

"Orang-orang yang memakan riba tidak dapat berdiri melainkan seperti berdirinya orang yang kemasukan setan karena gila. Yang demikian itu karena mereka berkata bahwa jual beli sama dengan riba. Padahal Allah telah menghalalkan jual beli dan mengharamkan riba. Barangsiapa mendapat peringatan dari Tuhannya, lalu dia berhenti, maka apa yang telah diperolehnya dahulu menjadi miliknya dan urusannya (terserah) kepada Allah. Barangsiapa mengulangi, maka mereka itu penghuni neraka, mereka kekal di dalamnya."( Q.S al-Baqarah: 275) (As-Suyuthi and Al-Mahally 2003).
Rasulullah dalam sebuah hadist yang di riwayatkan dari Ibn Bajjar dan al-Hakim telah menyahihkannya dari Rifa'ah Ibnu Rafi', beliau bersabda:

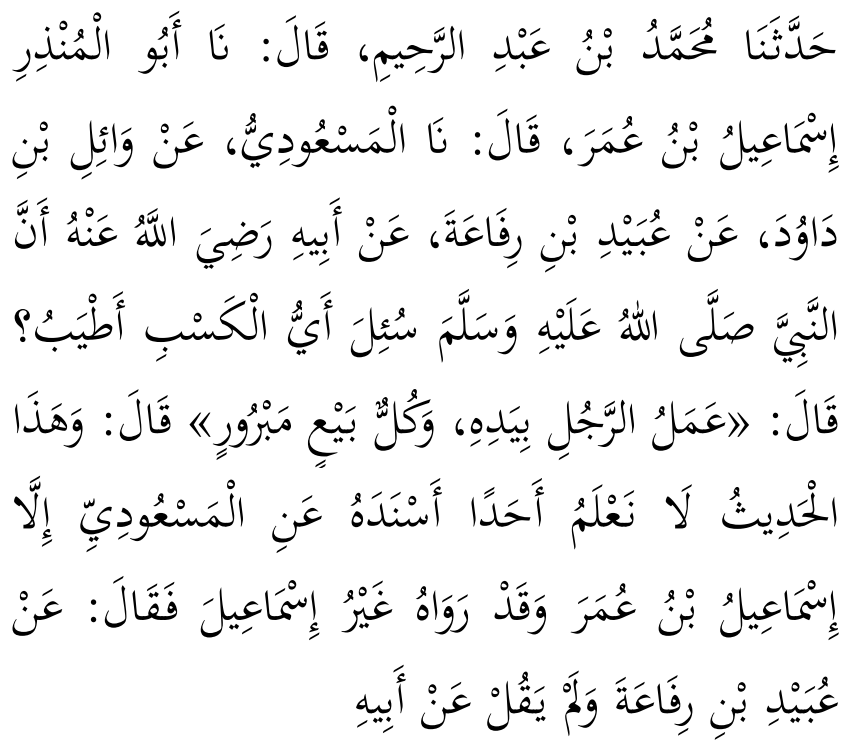

'Dari Rifa'ah bin Rafi' radiallahu 'anhu, bahwa Rasulullah SAW dittanya: "Apakah pekerjaan yang paling baik/Afdhol ?” Beliau menjawab: "Pekerjaan seorang laki-laki dengan tangannya sendiri (hasil jerih payah sendiri), dan setiap jual beli yang mabrur." (Hadist Riwayat al-Bazzar dan dishahihkan oleh al-Hakim) (خيري 2018).

Berdasarkan Jumhur Ulama (Ijma) bahwasanya para ulama telah sepakat bahwa jual beli diperbolehkan dengan alasan bahwa manusia tidak akan mencukupi kebutuhan dirinya, tanpa bantuan orang lain. Namun demikian, bantuan untuk barang milik orang lain yang dibutuhkannya itu, harus diganti dengan barang yang sesuai (Syafei 2006).

Berdasarkan rumusan masalah penelitian tersebut, maka tujuan dari penelitian ini adalah untuk mengetahui penerapan akad Istishna memiliki pengaruh terhadp minat beli masyarakat pada perumahan Nakhil Garden Pawarengan, dan untuk mengetahui seberapa besar pengaruh Penerapan akad Istishna terhadap minat masyarakat untuk membeli perumahan Nakhil garden Pawarengan. 


\section{TINJAUAN PUSTAKA \\ A. Pengertian Istishna}

Menurut bahasa berasal صنع (shana'a)yang artinya

dari kata kemudian ditambah huruf alif, sindan ta'menjadi استصنع(istashna'a) yang berarti meminta dibuatkan sesuatu. Transaksi jual beli istishna'merupakan kontrak penjualan antara mustashni'(pembeli ) dan shani'(pembuat barang/penjual). Dalam kontrak ini shani'menerima pesanan dari mustashni'.Shani'lalu berusaha sendiri ataupun melalui orang lain untuk membuat mashnu'(pokok kontrak) menurut spesifikasi yang telah disepakati dan menjualnya kepada mustashni'. Kedua belah pihak bersepakat atas harga serta sistem pembayaran (Muhammad Rizki Hidayah, Kholil Nawawi 2018).

Secara sederhana menurut istilah bahasa istishna itu menganggap sesuatu itu baik atau mencari yang terbaik di antara yang baik. Sedangkan istilah istishna itu diartikan berpindah dari suatu hukum kepada hukum lainnya atau memilih suatu hukum dan mengenyampingkan (mengabaikan) hukum lainnya, atau mengecualikan hukum yang bersifat kulli dengan hukum yang bersifat juz'i, atau mengadakan takhnis terhadap hukum yang bersifat umum (Winarno 2019).

Istishna didefinisikan sebagai akad meminta sesorang untuk membuat sebuah barang tertentu dalam bentuk yang sesuai berdasarkan bentuk barang yang diinginkan oleh pesanan. Istishna dibagikan sebagai akad yang dilakukan dengan seseorang untuk membuat barang tertentu dalam tanggungan (Wahbah Az-Zuhaili 2011). Jadi dalam akad istishna' barang yang menjadi objek adalah barang-barang buatan atau hasil karya. Adapaun bahan dasar yang digunakan untuk membuat barang tersebut adalah barang milik pembuatnya, apabila bahan dasarnya dari orang yang memesan maka akadnya bukan istishna' tetapi akad ijarah (Mustofa 2016).

Istishna' adalah akad yang berasal dari bahasa Arab artinya buatan. Menurut para ulama bay' Istishna' (jual beli dengan pesanan) merupakan suatu jenis khusus dari akad bay' as-salam (jual beli salam). Jenis jual beli ini dipergunakan dalam bidang manufaktur. Pengertian bay' Istishna' adalah akad jual barang pesanan di antara dua belah pihak dengan spesifikasi dan pembayaran tertentu. Barang yang dipesan belum diproduksi atau tidak tersedia di pasaran. Pembayarannya dapat secara kontan atau dengan cicilan tergantung kesepakatan kedua belah pihak (Mujiatun 2013).

\section{B. Dasar Hukum}

Berdasarkan kaidah fiqh menurut pendapat jumhur ulama bahwasanya hukum asal penerapan akad Istishna adalah boleh (Huda 2015)

"Pada dasarnya, semua bentuk muamalah adalah boleh kecuali ada dalil yang mengharamkannya"

Menurut Sutan Reimi Istishna merupakan akad yang mengandung tuntutan agar tukang/ahli (shani') membuatkan suatu pesanan dengan ciri-ciri khusus, maka istishna' adalah jual beli antara pemesan dan penerima pesanan, dimana spesifikasi dan harga barang disepakati di awal sedangkan pembayaran dilakukan secara bertahap sesuai kesepakatan (Sjahdein 2014).

Menurut ulama Fiqh, Istishna sama dengan jual Salam dari segi objek pesanan, yang mana sama- sama harus di pesan terlebih dahulu dengan ciri- ciri/ kriteria khusus yang di kehendaki pembeli. Perbedaannya: pembayaran pada jual beli salam di dibayar lunas diawal akad sekaligus. Sedangkan pembayaran pada akad Istishna dapat dilakukan pada awal akad atau setelah akad, dapat dilakukan ditengah, dan dapat pula 
dilakukan diakhir setelah barang selesai sesuai dengan perjanjian (Ayyub 2009).

\section{Rukun Istishna}

Menurut Syafii Antonio Rukun istishna adalah sebagai berikut (Syafi'I Antonio 2005):

1. Al-mustashni (pembeli/pemesan)

a. Menentukan spesifikasi barang yang di pesan

b. Tidak boleh menjual barang sebelum menrimanya.

c. Jika barang tidak sesuai dengan kesepakatan, pemesan memiliki hak pemilih untuk melanjutkan atau membatalkan akad.

2. As - shani (penjual)

a. Boleh menjual barang yang dibuat oleh orang lain dengan kualitas dan kuantitas yang dikehendaki oleh pemesan.

b. Tidak menukar barang kecuali dengan barang yang sejenis sesuai dengan kesepakatan

3. Al- mashu (barang yang dijual)

a. Harus jelas ciri dan Spesifikasinya

b. Barang yang dipesan adalah barang yang biasa dijul belikan secara pesanan oleh orang banyak

c. Waktu dan tempat penyerahan barang ditentukan sesuai kesepakatan

d. Bahan yang digunakan milik penjual

4. Harga

a. Harga juga boleh dibayar semua pada saat penyerahan barang

b. Secara angsuran sesuai dengan kesepakatan

c. Pembayaran tidak boleh dalam bentuk pembebasan utang

5. Sighat atau Ijab Kabul
a. Modal harus diketahui
b. Penerimaan pembayaran salam
c. Harus spesifik dan dapat diakui sebagai utang

d. Dapat diidentifikasi secara jelas

Menurut Madhab Hanafi yang menyetujui akad Istihsna, hal ini dengan berdasarkan pada hal berikut ini (Nurul 2010):

1. Masyarakat telah memperaktekan Istishna secara luas dan terus menerus tanpa ada keberatan sama sekali. maka Istishna "sebagai kasus ijma" atau consensus umum.

2. Istishna sah sesuai dengan aturan umum mengenai kebolehan kontrak selama tidak bertentangan dengan nash atau aturan syariah

3. Keberadaan Bai'Al-Istishna' berdasarkan atas kebutuhan masyarakat. Banyak yang sering kali memberikan barang yang tidak tersedia di pasar sehingga mereka cenderung melakukan kontrak agar orang lain membuat barang untuk mereka.

\section{Perbandingan Penelitian Terdahulu}

Penelitian tentang "Penerapan akad Istishna telah di telaah oleh beberapa penelitipeneliti terdahulu diantaranya adalah sebagai berikut:

1. Jual Beli Istishna Pada Penjualan Sampan Di Desa Pangkalan Terap Kecamatan Teluk Meranti Kabupaten Pelalawan (Indra 2013)

Hasil penelitiannya menyatakan bahwa konsep yang diterapkan dalam bisnis ini sebagian telah menyentuh konsep Istishna, hal ini dapat dilihat dari segi pemesanan dan pembayaran yang dilakukan oleh penjual dan pembeli pada saat akad, yaitu dalam pemenuhan barang oleh penjual kepada pembeli diterapkan sistem pemesanan terlebih dahulu, dan untuk sistem pembayarannya dilakukan diakhir yaitu pada saat barang telah dipenuhi. Hal ini sudah sesui dengan konsep Istishna, akan tetapi di lain sisi yaitu dari segi pengiriman barang ke pembeli terkadang tidak sesui dengan apa yang telah 
diperjanjikan pada saat akad, dan hal tersebut tidak sesuai dengan akad Istishna.

Perbedaan penelitian terdahulu dengan penelitian saat ini adalah perbandingan terdahulu menganalisis penerapan Jual Beli Istishna Pada Penjualan Sampan Di Desa Pangkalan Terap Kecamatan Teluk Meranti Kabupaten Pelalawan. Peneliti terdahulu mempunyai tujuan untuk mengenalisa jual beli isthisna pada penjulana smapan. Sedangkan peneliti saat ini tentang Pengaruh Penerapan Akad Isthisna Terhadap Minat Beli Masyarakat Di Perumahan Nakhil Garden Pawarengan Cikampek Barat. perbedaan lainnya terdapat pada tujuan penelitian yang di lakukan, penelitian saat ini mempunyai tujuan untuk mengetahui penerapan akad Istishna memiliki pengaruh terhadap minat beli masyarakat pada perumahan Nakhil Garden Pawarengan, dan untuk mengetahui seberapa besar pengaruh Penerapan akad Istishna terhadap minat masyarakat untuk membeli perumahan Nakhil garden Pawarengan.

2. Akad Istishna Dalam Pembiayaan Rumah Pada Bank Syariah Mandiri : Studi Kasus Pada Bank Syariah Mandiri Kantor Cabang Pembantu Cinere" (Marduwira 2010)

Hasil penelitian Erdi Marduwira menyatakan bahwa akad Istishna dalam pembiyaan rumah yang diterapkan oleh Bank Mandiri Syariah tidak sepenuhnya berjalan dengan lancar, hal ini dikarenakan pada saat akad, nasabah tidak memberikan data yang jujur sebagai syarat dalam pembiayaan, sehingga banyak dari nasabah tidak lancar dalam pembayaran (macet), terlebih dari pihak Bank pun tidak meneliti secara mendalam mengenai data-data yang oleh nasabah. Sehingga banyak kelolosan yang terjadi.

Perbedaan penelitian terdahulu dengan penelitian saat ini adalah perbandingan terdahulu menganalisis penerapan Akad Istishna dalam Pembiayaan Rumah pada Bank Syariah Mandiri. Peneliti terdahulu mempunyai tujuan untuk mengetahui penerapan akad istishna dalam pembiayaan rumah pada bank syariah mandiri. Sedangkan peneliti saat ini tentang Pengaruh Penerapan Akad Isthisna Terhadap Minat Beli Masyarakat Di Perumahan Nakhil Garden Pawarengan Cikampek Barat. perbedaan lainnya terdapat pada tujuan penelitian yang di lakukan, penelitian saat ini mempunyai tujuan untuk mengetahui penerapan akad Istishna memiliki pengaruh terhadp minat beli masyarakat pada perumahan Nakhil Garden Pawarengan, dan untuk mengetahui seberapa besar pengaruh Penerapan akad Istishna terhadap minat masyarakat untuk membeli perumahan Nakhil garden Pawarengan.

3. Penerapan Akad Istishna Terhadap Sistem Pemasaran Industri Meubel dalam Perspektif Ekonomi Islam (Studi Kasus pada Kawasan Pengrajin Meubel di Antang Kota Makasar" (Ramli 2017)

Berdasarkan hasil penelitiannya, Muh Ramli menyatakan bahwa pada bisnis Meubel di Antang Kota Makasar telah menerapkan sistem akad Istishna pada usaha yang digelutinya sebagimana mestinya, yaitu dari segi pembayaran dilakukan di awal dan sebagian di akhir, kondisi barang sesuai dengan pesanan pembeli dan pengiriman sesuai dengan yang diperjanjikan, hal-hal tersebut sudah menyentuh ke dalam konsep Istishna.

Peneliti terdahulu mempunyai tujuan untuk mengenalisa Penerapan Akad Istishna Terhadap Sistem Pemasaran Industri Meubel dalam Perspektif Ekonomi Islam. Sedangkan peneliti saat ini tentang Pengaruh Penerapan Akad Isthisna Terhadap Minat Beli Masyarakat Di Perumahan Nakhil Garden Pawarengan Cikampek Barat. perbedaan lainnya terdapat pada tujuan penelitian yang di lakukan, penelitian saat ini mempunyai tujuan untuk

EKSISBANK (Ekonomi Syariah dan Bisnis Perbankan), Volume 5, Nomor 2, Desember 2021 
mengetahui penerapan akad Istishna memiliki pengaruh terhadap minat beli masyarakat pada perumahan Nakhil Garden Pawarengan, dan untuk mengetahui seberapa besar pengaruh Penerapan akad Istishna terhadap minat masyarakat untuk membeli perumahan Nakhil garden Pawarengan.

Berdasarkan hasil penelitian dari penelitipeneliti terdahulu diatas, penulis belum menemukan penelitian terkait penerapan akad Isthtisna terhadap penjualan proferti (perumahan) dari Developer proferti (perumahan) dengan Konsumen tanpa pembiayaan Bank.

Berdasarkan kesimpulan diatas, penulis tertarik untuk menelaah lebih mendalam lagi terkait penerapan akad Isthtisna terhadap penjualan proferti (Perumahan) tanpa pembiayaan Bank. Dalam hal ini peneliti memfokuskan pada Perumahan Nakhil Garden Pawarengan sebagai objek penelitian. Karena perumahan Nakhil Garden Pawarengan menerapkan akan Istishna penjualan profertinya. Hal ini bertujuan untuk mengetahui penerapan akad Isthtisna yang diterapkan oleh Perumahan Nakhil Garden Pawarengan berpengaruh terhadap minat masyarakat untuk membeli produknya, dan seberapa besar pengaruh penerapan akad Isthtisna tersebut terhadap minat belinya.

Sedangkan peneliti saat ini tentang Pengaruh Penerapan Akad Isthisna Terhadap Minat Beli Masyarakat Di Perumahan Nakhil Garden Pawarengan Cikampek Barat. perbedaan lainnya terdapat pada tujuan penelitian yang di lakukan, penelitian saat ini mempunyai tujuan untuk mengetahui penerapan akad Istishna memiliki pengaruh terhadp minat beli masyarakat pada perumahan Nakhil Garden Pawarengan, dan untuk mengetahui seberapa besar pengaruh Penerapan akad Istishna terhadap minat masyarakat untuk membeli perumahan Nakhil garden Pawarengan.

\section{METODOLOGI PENELITIAN}

Penelitian ini dilakukan di wilayah kabupaten Karawang, Propinsi Jawa Barat. Tepatnya di perumahan Nakhil Garden Pawarengan yang terletak di Desa Pawarengan, Cikampek Barat, Kecamatan Cikampek. Adapun lamanya waktu penelitian adalah 6 bulan terhitung dari bulan April 2018 sampai September 2018.

Metodologi yang digunakan pada penelitian ini adalah metode Deskriptif Kuantitatif, yang bertujuan untuk memberikan deskripsi, gambaran atau lukisan secara sistematis, faktual, dan akurat mengenai fakta-fakta, sifat-sifat serta hubungan antar fenomena yang tengah diteliti.

Populasi dalam penelitian ini adalah calon pembeli dan pembeli Perumahan Nakhil Garden Pawarengan Cikampek Barat. Populasi menurut Suhardi merupakan wilayah generalisasi yang terdiri atas objek/subjek yang mempunyai kualitas dan karakteristik tertentu yang ditetapkan oleh peneliti untuk dipelajari dan kemudian ditarik kesimpulannya (Purwanto 2007).

Berdasarkan populasi diatas maka sampel yang digunakan pada penelitian ini merupakan bagian dari populasi. Menurut Suharsimi Arikunto Sampel merupakan penelitian yang dilakukan terhadap sebagian saja atau wakil dari populasi, akan tetapi hasil penelitiannya berlaku bagi semua subjek yang tergabung sebagai populasi (Arikunto 2016). Oleh karena itu, sampel merupakan bagian jumlah dan karakteristik yang dimiliki oleh populasi. Dikarenakan keterbatasan dana, tenaga dan waktu, peneliti tidak dapat mempelajari seluruk subjek dari populasi, maka peneliti menggunakan sampel ini untuk dipelajari. Sampel yang digunakan merupakan subjek yang refresentatif (mewakili), sehingga kesimpulan yang 
didapat dari akan diberlakukan untuk seluruh populasi (Sugiyono 2017). Penelitian ini dari populasi yang tidak diketahui jumlahnya adalah menggunakan rumus yang dikembangkan dari Isaac yang diambil dari buku Statistika Untuk Penelitian karya Sugiyono berikut:

$$
\begin{aligned}
& \mathrm{S}=\quad \lambda^{2} \text {.N.P.Q } \\
& \mathrm{d}^{2}(\mathrm{~N}-1)+\lambda 2 . P . Q \\
& \text { Dimana : } \\
& \mathrm{S} \text { : Jumlah sampel }
\end{aligned}
$$

$\lambda 2$ : Chi Kuadrat yang harganya tergantung derajat kebebasan dan tingkat kesalahan. Unyuk Derajat kebebasan dan kesalahan 5\% harga Chi Kuadrat = 3.841 .

$\mathrm{N}$ : Jumlah populasi

$\mathrm{P}$ : Peluang benar $9(0.5)$

$\mathrm{Q}$ : Peluang salah (0.5)

$\mathrm{d}$ : Perbedaaan antara rata-rata sampel dengan rata-rata populasi. Yaitu 0.05

Maka :

$$
\begin{aligned}
& \mathrm{S}=\frac{\lambda{ }^{2} \text {.N.P.Q }}{\mathrm{d}^{2}(\mathrm{~N}-1)+{ }^{2} \text {.P.Q } \lambda} \\
& =\frac{3,841 \cdot 45 \cdot 0,5 \cdot 0,5}{0} \\
& 0.05^{2}(45-1)+3,841 \cdot 0,5.0,5 \\
& =\frac{43,21125}{1,07025} \\
& =40,37
\end{aligned}
$$$$
=40(\text { Dibulatkan }
$$

Bardasarkan perhitungan sampel menggunakan rumus Isaac Michael diatas, dapat kita ketahui bahwa sampel yang harus digunakan pada penelitian ini dengan menggunakan populasi sebanyak 45 yang terdiri dari konsumen dan calon konsumen adalah sebanyak 40 .

Teknik sampling dalam penelitian ini adalah dengan menggunakan Probabiliti sampling dengan metode Simple Random Sampling. Simple Random Sampling atau pengumpulan data secara acak sederhana merupakan pengambilan anggota sampel dari populasi tanpa memperhatikan strata yang ada dalam populasi tersebut. Pengambilan sampel acak sederhana dapat dilakukan dengan cara undian, memilih secara acak, dan sebagainya.

Data primer yang digunakan diperoleh secara langsung dari pihak pertama melalui wawancara, observasi, dan kuesioner. Sedangkan, data sekunder pada penelitian ini merupakan data tak langsung yang diperoleh dari sumber lain seperti buku, jurnal dan artikel yang berhubungan dengan penelitian.

Teknik analisa data pada penelitian ini meliputi uji validitas, uji Realibilitas, uji normalitas dan uji koefisian (t) atau uji parsial. Uji validasi digunakan untuk mengukur valid tidaknya suatu kuesioner. Suatu kuesioner dikatakan valid jika pertanyaan pada kuesioner mampu untuk mengungkapkan sesuatu yang diukur oleh kuesioner.

Uji Reabilitas dilakukan untuk mengukur semua kuesioner yang merupakan indikator dari variabel. Suatu kuesioner dikatakan reliable atau handal jika jawaban seseorang terhadap pertanyaan adalah konsisten atau stabil dari waktu ke waktu.

Uji normalitas dilakukan untuk mengetahui normalitas dari sebuah sampel. Uji normalitas bertujuan untuk menguji apakah dua atau lebih populasi memiliki distribusi yang sama.

Uji parsial atau Uji koefisien (t), yaitu untuk menguji bagaimana pengaruh masingmasing variabel bebasnya secara sendirisnediri terhadap variabel terikatnya. Dalam hal ini untuk menguji pengaruh variabel "Penerapan Akad Istishna" terhadap variabel "Minat Beli Masyarakat"

\section{HASIL DAN PEMBAHASAN}

\section{A. Karakteristik Responden}

Perumahan Nakhil Garden, Nakhil dalam bahasa Arab artinya pohon kurma dan Garden adalah kebun. Jadi perumahan berdasarkan teknik Probabiliti sampling dengan metode 
Simple Random Sampling yang digunakan pada penelitian ini, berikut merupakan data deskripsi responden yang merupakan sampel penelitian.

Diagram 4.1

Data Responden Berdasarkan Jenis Kelamin

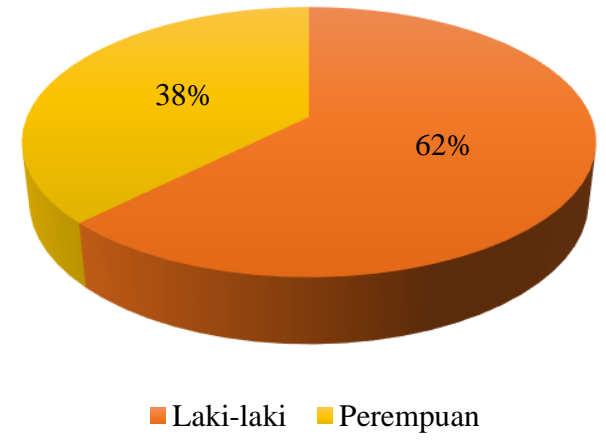

Sumber : Dokumen Penulis

Berdasarkan data pada tabel diatas dapat diketahui bahwa responden pada penelitian ini terdiri dari laki-laki $62 \%$ dan perempuan $38 \%$. Atau berjumlah 25 responden untuk laki-laki dan 15 orang untuk responden perempuan.

\section{Diagram 4.2}

Data Responden Berdasarkan Usia

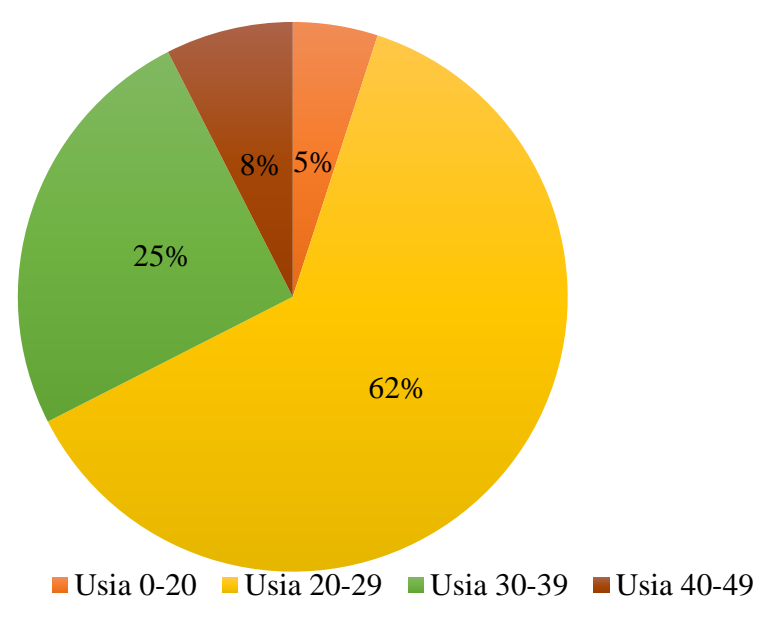

Sumber : Dokumen Penulis

Bedasarkan usia responden ketahui bahwa: responden usia $0-20$ tahun $5 \%$, usia 20-29 tahun 62\%, usia 30-39 tahun 25\%, usia 40-49 tahun 8\%. Berdasarkan jenis pekerjaan responden diketahui bahwa responden yang bekerja sebagai Pekerja Swasta adalah sebanyak 77\%, responden yang bekerja sebagai Pengajar adalah sebanyak 5\%, responden yang bekerja sebagai Wiraswasta adalah sebanyak 5\% dan lain-lain adalah sebanyak $13 \%$.

\section{Diagram 4.3}

Data Responden Berdasarkan Tingkat Pendidikan

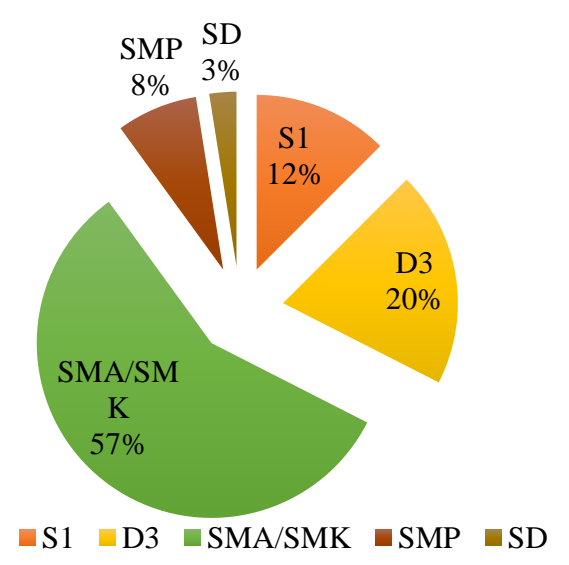

Sumber : Dokumen Penulis

Berdasarkan data yang ditampulkan pada tabel diatas, dapat diketahui bahwa responden pada penelitian ini ditinjau dari latar belakang pendidikannya adalah sebagai berikut:

1.Responden lulusan S1 sebanyak 12\% atau sejumlah 5 responden.

2. Responden lulusan D3 sebanyak 20\% atau sejumlah 8 responden

3. Responden lulusan SMA/SMK sebanyak 57\% atau sejumlah 23 responden

4. Responden lulusan SMP sebanyak 8\% atau sejumlah 3 responden.

5. Responden lulusan SD sebanyak 3\% atau sejumlah 1 responden.

Diagram 4.4

Data Responden Berdasarkan Status Pekerjaan

EKSISBANK (Ekonomi Syariah dan Bisnis Perbankan), Volume 5, Nomor 2, Desember 2021 


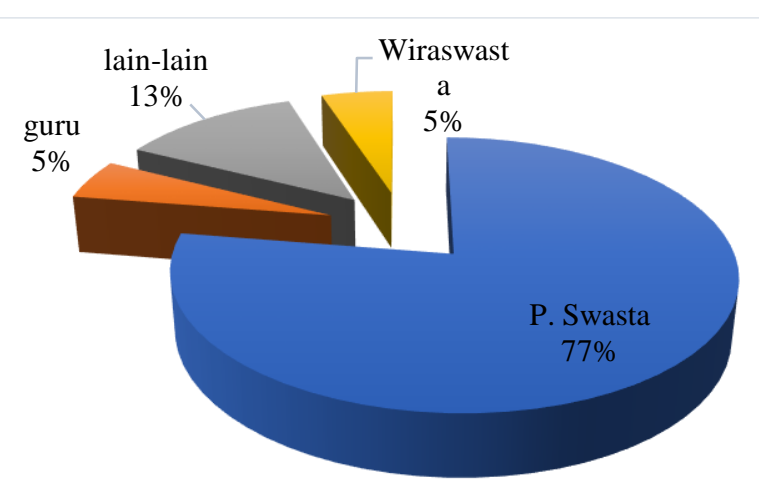

- P. Swasta guru lain-lain Wiraswasta

Sumber : Dokumen Penulis

Berdasarkan data yang ditampilkan pada tabel diatas, dapat diketahui bahwa responden pada penelitian ini berdasarkan pekerjaannya dalah sebagai berikut:

1.Responden yang bekerja sebagai Pekerja Swasta adalah sebanyak $77 \%$ atau sejumlah 31 responden.

2.Responden yang bekerja sebagai Pengajar adalah sebanyak 5\% atau sejumlah 2 responden.

3.Responden yang bekerja sebagai Wiraswasta adalah sebanyak $5 \%$ atau sejumlah 2 responden.

4.Dan responden yang bekerja sebagai Lainlain adalah sebanyak $13 \%$ atau sejumlah 5 responden.

\section{B. Hasil Uji Statistik}

\section{Hasil Uji Validitas}

Berdasarkan hasil uji validitas data pada penelitian ini, diketahui bahwa nilai $r$ tabel untuk sampel dari populasi 45 responden dengan taraf signifikan 0.05 adalah sebesar $0.312 .{ }^{25}$ seperti pada table berikut:

Tabel 4.1

Hasil Uji Validita variable X

Correlations

\begin{tabular}{|l|c|c|c|c|}
\hline No. Soal & r hitung & $\mathrm{r}$ table & $\begin{array}{c}\text { sig } \\
0.05\end{array}$ & Keptusan \\
\hline $\mathrm{x} 1$ & 0.516 & 0.312 & 0 & Valid \\
\hline $\mathrm{x} 2$ & 0.611 & 0.312 & 0 & Valid \\
\hline $\mathrm{x} 3$ & 0.55 & 0.312 & 0 & Valid \\
\hline
\end{tabular}

\begin{tabular}{|l|c|c|c|c|}
\hline x4 & 0.64 & 0.312 & 0 & Valid \\
\hline x5 & 0.715 & 0.312 & 0 & Valid \\
\hline x6 & 0.539 & 0.312 & 0 & Valid \\
\hline x7 & 0.742 & 0.312 & 0 & Valid \\
\hline X8 & 0.639 & 0.312 & 0 & Valid \\
\hline \\
**. Correlation is significant at the 0.01 level (2-tailed). \\
*. Correlation is significant at the 0.05 level (2-tailed).
\end{tabular}

Berdasarkan tabel 4.1, jika nilai $\mathrm{r}$ hitung $>0.05$ ( $\mathrm{r}$ tabel) maka item tersebut di katakana valid. Sebaliknya jika nilai $r$ hitung $\leq 0.05$ ( $\mathrm{r}$ tabel) maka item tersebut dikatakan tidak valid. Pada tabel diatas dapat dilihat bahwa nilai $r$ hitung terkecilnya adalah 0.516. Artinya $0.516 \geq 0.312$. Dengan demikian, maka item tersebut dinyatakan valid.

Berikut ini merupakan hasil uji validitas pada penelitian ini yakni variabel Y (Minat Beli) dengan pengujian data menggunakan program SPSS versi 20. Hasil pengujian ditampilkan pada table berikut:

Tabel 4.2

Hasil Uji Validitas Variabel Y

\section{Correlations}

\begin{tabular}{|c|c|c|c|c|}
\hline No. Soal & $\mathrm{r}$ hitung & $\mathrm{r}$ table & sig 0.05 & Keputusan \\
\hline $\mathrm{y} 1$ & 0.641 & 0.312 & 0 & Valid \\
\hline $\mathrm{y} 2$ & 0.764 & 0.312 & 0 & Valid \\
\hline $\mathrm{y} 3$ & 0.822 & 0.312 & 0 & Valid \\
\hline $\mathrm{y} 4$ & 0.85 & 0.312 & 0 & Valid \\
\hline y5 & 0.831 & 0.312 & 0 & Valid \\
\hline y6 & 0.727 & 0.312 & 0 & Valid \\
\hline $\mathrm{y} 7$ & 0.665 & 0.312 & 0 & Valid \\
\hline
\end{tabular}

Berdasarkan pada tabel 4.2 yang ditampilkan pada table diatas, diketahui bahwa nilai $r$ hitung variabel y sebesar 0.641 dan nilai $r$ tabel sebesar 0.312. Maka dapat ditarik pemahaman bahwa nilai $r$ hitung $0.641 \geq 0.312$. Dengan demikian variabel $y$ pada penelitian ini disimpulkan valid.

\section{Hasil Uji Reliabilitas}

Uji reabilitas menggunakan program SPSS versi 20 dengan metode membandingkan

EKSISBANK (Ekonomi Syariah dan Bisnis Perbankan), Volume 5, Nomor 2, Desember 2021 
angka Cronbach alpha dengan rumus sebagai berikut dengan ketentuan nilan Cronbach alpha minimal adalah 0.6 (Sugiyono 2017).

Jika nilai uji pada taraf signifikasi $\mathrm{x}$ sebesar 0.05. Maka instrumen dari hasil perhitungan program SPSS dapat dikatakan reliable jika Cronbach alpha lebih besar dari 0.6. Sebaliknya jika nilai Cronbach alpha lebih kecil dari 0.6 maka disimpulkan kuesioner tersebut tidak reliable. Perhatikan tabel hasil perhitungan program SPSS berikut ini.

Tabel 4.3

Hasil Uji Reabilitas Variabel X Reliability Statistics

\begin{tabular}{|c|c|}
\hline Cronbach's Alpha & $\mathrm{N}$ of Items \\
\hline .757 & 8 \\
\hline
\end{tabular}

Berdasarkan tabel 4.3 dapat diketahui bahwa nilai Cronbach Alpha variabel x sebesar 0.757, artinya lebih besar dari 0.6. jika dinyatakan dalam angka maka dapat di tulis $0.757>0.6$.

Dengan demikian variabel $\mathrm{x}$ dalam penelitian ini yaitu Penerapan Akad Istishna dinyatakan reliable. Berikut merupakan tabel hasil pengujian reabilitas variabel y dengan menggunakan program SPSS versi 20

Tebel 4.4

Hasil Uji Realibitas variabel y

Reliability Statistics

\begin{tabular}{|c|c|}
\hline Cronbach's Alpha & N of Items \\
\hline .875 & 7 \\
\hline
\end{tabular}

Berdasarkan tabel 4.4 dapat diketahui bahwa nilai Cronbach Alpha variabel x sebesar 0.875 artinya lebih besar dari 0.6, jika dinyatakan dalam angka maka dapat di tulis $0.875>0.6$. Dengan demikian variabel $\mathrm{Y}$ dalam penelitian ini yaitu Minat Beli dinyata kan reliable.

\section{Hasil Uji Normalitas}

Uji normalitas pada penelitian ini dasar pengambilan keputusannya adalah jika nilai signifiksi >0.05 maka nilai residual berdistribusi normal. Sebaliknya, jika nilai signifikasi $<0.05$ maka nilai residual tidak berditribusi normal.

Tabel 4.5

Hasil Uji Normalitias

One-Sample Kolmogorov-Smirnov Test

\begin{tabular}{|c|r|}
\hline & \multicolumn{1}{|c|}{$\begin{array}{c}\text { Unstandardiz ed } \\
\text { Residual }\end{array}$} \\
\hline $\mathrm{N}$ & 40 \\
\hline \multicolumn{1}{|c|}{ Mean } & 0E-7 \\
\hline $\begin{array}{c}\text { Normal Parameters, } \\
\text { Deviation }\end{array}$ & 3.22285269 \\
\hline \multicolumn{1}{|c|}{ Absolute } & .094 \\
\hline $\begin{array}{l}\text { Most Extreme Differences } \\
\text { Positive }\end{array}$ & .074 \\
\hline \multicolumn{1}{|c|}{ Negative } & -.094 \\
\hline Kolmogorov-Smirnov Z & .595 \\
\hline Asymp. Sig. (2-tailed) & .871 \\
\hline
\end{tabular}

a. Test distribution is Normal.

b. Calculated from data

Berdasarkan data yang diperlihatkan pada tabel diatas, maka dapat dianalisa bahwa data tersebut memiliki nilai signifikasi sebesar $0.871>0.05$. Dengan demikian, maka nilai residual $\mathrm{x}$ terhadap y adalah berdistribusi normal. Berikut ini hasil pengujian yang ditampilkan dalam bentuk histogram

Tabel 4.6

\section{Grafik Uji Normalitas Data}

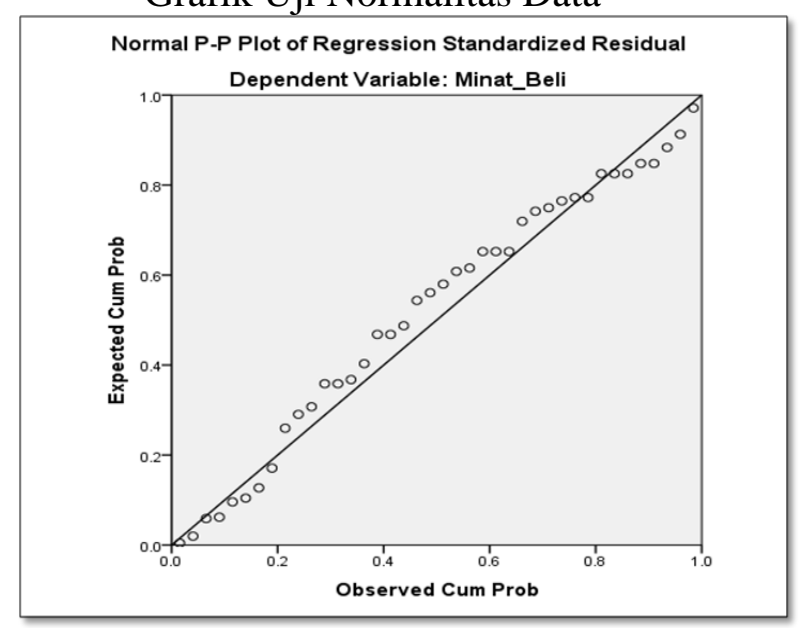

Dasar pengabilan keputusan berdasarkan data yang di tampilkan pada histogram diatas, menurut Sayid Raharjo bahwa:

1. Data dikatakan terdistribusi normal, jika

EKSISBANK (Ekonomi Syariah dan Bisnis Perbankan), Volume 5, Nomor 2, Desember 2021 
data atau titik menyebar di sekitar garis diagonal dan mengikuti arah garis diagonal.

2. Sebaliknya data dikatakan tidak terdistribusi normal, jika data atau titik menyebar jauh dari arah garis atau tidak mengikuti garis diagonal.

Berdasarkan data histogram tersebut diketahui bahwa data atau titik menyebar di sekitar garis diagonal dan mengikuti arah garis diagonal. Maka variable (x) Penerapan Akad Istishna bernilai residual normal terhadap variabel (y) Minat Beli.

\section{Hasil Uji T}

Uji t atau uji parsial dilakukan untuk menguji variabel x (Penerapan Akad Istishna) berpengaruh terhadap variabel y (minat Beli). Berikut data $t$ hitung dan $t$ tabel yang diolah menggunakan program SPSS versi 20.

Tabel 4.7

Hasil pengujian variabel dengan uji $\mathrm{t}$ Model Summary ${ }^{\mathrm{b}}$

\begin{tabular}{|c|c|c|c|c|}
\hline Model & $\mathrm{R}$ & $\begin{array}{c}\mathrm{R} \\
\text { Square }\end{array}$ & $\begin{array}{l}\text { Adjusted } \\
\text { R Square }\end{array}$ & $\begin{array}{l}\text { Std. Error of } \\
\text { the Estimate }\end{array}$ \\
\hline 1 & $.432^{\mathrm{a}}$ & .187 & .165 & 3.26498 \\
\hline
\end{tabular}

a. redictors: (Constant), Penerapan_Akad_Istishna

b. Dependent Variable: Minat_Beli

Dasar pengambilan keputusan untuk uji $\mathrm{t}$ pada penelitian ini adalah jika nilai sig $<0.05$ atau $\mathrm{T}$ hitung $>\mathrm{t}$ tabel maka terdapat pengaruh variabel $x$ terhadap variabel $Y$. jika nilai sig >0.05 atau $\mathrm{t}$ hitung $<\mathrm{t}$ tabel maka tidak terdapat pengaruh variabel $\mathrm{x}$ terhadap variabel Y.

\section{C.Pengaruh Penerapan Akad Istishna Terhadap Minat Beli Masyarakat Pada Perumahan Nakhil Garden Pawarengan Cikampek}

Pengaruh penerapan akad Istishna terhadap Penjualan rumah di perumahan Nakhil Garden Pawarenagn tidak memberikan pengaruh yang signifikan terhadap minat beli Masyarakat untuk memiliki hunian di perumahan Nakhil Garden Pawarengan Cikampek Barat.

\section{Besaran Pengaruh Penerapan Akad Istishna Terhadap Minat Masyarakat Untuk Membeli Perumahan Nakhil Garden Pawarengan Cikampek}

Berdasarkan data yang di tampilkan pada tabel diatas menjelaskan bahwa terdapat nilai korelasi / hubungan (R) sebesar 0.432a, dan nilian koefisien determinasi atau ( $\mathrm{R}$ Square) sebesar 0.187, artinya pengaruh variabel bebas (Penerapan Akad Istishna) terhadap variabel terikat (Minat Beli) adalah sebesar $18.7 \%$, sedangkan sisanya sebesar $81.3 \%$ dipengaruhi oleh faktor lain yang tidak dijelaskan dalam penelitian ini.

\section{KESIMPULAN}

Berdasarkan hasil dari pengujian data dalam penelitian ini, maka dapat ditarik kesimpulan bahwa Pengaruh penerapan akad Istishna terhadap Penjualan rumah di perumahan Nakhil Garden Pawarenagn tidak memberikan pengaruh yang signifikan terhadap minat beli Masyarakat untuk memiliki hunian di perumahan Nakhil Garden Pawarengan Cikampek Barat.

Berdasarkan hasil uji regresi tersebut dapat diketahui bahwa nilai koefisien determinasi (R Square) yang dihasilkan adalah sebesar 0.187 dari nilai korelasi / hubungan (R) sebesar 0.432 . Dengan demikian berdasarkan data tersebut dapat diartikan bahwa Penerapan Akad Istishna memberikan pengaruh terhadap Minat Beli pada perumahan Nakhil Garden Pawarengan sebesar $18,7 \%$, sisanya $81,3 \%$ dipengaruhi oleh faktor lain yang tidak di teliti pada penelitian ini.

\section{DAFTAR PUSTAKA}

Arikunto, Suharsimi. 2016. Manajemen

EKSISBANK (Ekonomi Syariah dan Bisnis Perbankan), Volume 5, Nomor 2, Desember 2021 
Penelitian. Jakarta: Rineka Cipta.

As-Suyuthi, Jalaluddin, and Jalaluddin Muhammad Ibnu Ahmad Al-Mahally. 2003. Tafsir Jalalain (Terjemahan). Imaratullah. Surabaya: Imaratullah.

Ayyub, Muhammad. 2009. Keuangan Syariah. Jakarta: Jakarta : PT Raja Gramedia Pustaka Utama.

Hasan, Ali. 2009. Manajemen Bisnis Syari'ah: Kaya Di Dunia Terhormat Di Akhirat. Yogyakarta: Pustaka Pelajar.

Huda, Nur. 2015. "Perubahan Akad Wadi'ah." Economica: Jurnal Ekonomi Islam 6, no. 1: 129-54.

Indra. 2013. "Jual Beli Istishna Pada Penjualan Sampan Di Desa Pangkalan Terap Kecamatan Teluk Meranti Kabupaten Pelalawan.” Universitas Islam Negeri Sultan Syarif Kasim Riau.

Marduwira, E. 2010. "Akad Istishna Dalam Pembiayaan Rumah Pada Bank Syariah Mandiri: Studi Kasus Pada Bank Syariah Mandiri Kantor Cabang Pembantu Cinere." Universitas Islam Negeri (UIN) Syarif Hidayatullah.

Muhammad Rizki Hidayah, Kholil Nawawi, Suyud Arif. 2018. "Analisis Implementasi Akad Istishna Pembiayaan Rumah (Studi Kasus Developer Property Syariah Bogor)." Ekonomi Islam (MEI) Vol. 9 No.

Mujiatun, Siti. 2013. "Jual Beli Dalam Perspektif Islam : Salam Dan Istisna'." Riset Akuntansi Dan Bisnis Vol 13 No. https://doi.org/http://dx.doi.org/10.30596\%2 Fjrab.v13i2.149.

Mustofa, Imam. 2016. Fiqih Mu'amalah Kontemporer,. Jakarta: PT. Raja Grafindo Persada.

Nurul, Huda. 2010. Lembaga Keuangan Islam. Jakarta: Kencana.

Peace, Andika Wijaya dan Anata Wida. 2017. AnHukum Bisnis Properti Di Indonesia. Jakarta: PT. Grasind.
Purwanto, Suharyadi dan. 2007. Statistika: Untuk Ekonomi Keuangan Modern. Jakarta: Salemba Empa.

Ramli, Muh. 2017. 'Penerapan Akad Istishna' Terhadap Sistem Pemasaran Industri Meubel Dalam Perspektif Ekonomi Islam (Studi Kasus Pada Kawasan Pengrajin Meubel Di Antang Kota Makassar)." Universitas Islam Negeri Alauddin Makassar.

Sjahdein, Sutan Remi. 2014. Perbankan Syariah Produk-Produk Dan Aspek-Aspek Hukumnya. Jakarta: Prenadamedia Group.

Sugiyono. 2017. Statistika Untuk Penelitian. Bandung: Alfabeta.

Syafei, Rachmat. 2006. Fiqih Muamalah. Bandung: Pustaka Setia.

Syafi'I Antonio, Muhammad. 2005. Bank Syari'ah Dari Teori Ke Praktek. Jakarta: Gema Insani Pers.

Wahbah Az-Zuhaili. 2011. Fiqih Islam Wa Adillatuhu. Jakarta: Gema Insani.

Wardhani, Nurul, and others. 2015. "Analisis Kelayakan Investasi Properti Pembangunan Ruko Dengan Sistem Bangun Bagi (Studi Kasus Lahan Di Jalan Danau Sentarum Kota Pontianak)." Jurnal Mahasiswa Teknik Sipil Universitas Tanjungpura 1, no. 1.

Wijaya, Andika, and Wida Peace Ananta. 2017.

Hukum Bisnis Properti Indonesia. Jakarta: Gramedia Widiasarana Indonesia.

Winarno. 2019. "Eksistensi Istihsandalam Istinbath Hukum Menurut Imam Hanafi." Al-Quwwah: Jurnal Pengabdian Masyarakat Vol. 2, No.

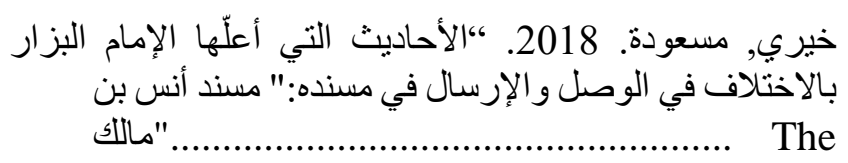

Traditions Considered as Differing in Continuity and Interruption by Imam Bazzar in His Musnad: Musnad." Al- Dirasat AlIslamiyyah 53 الدراسات الإسلامية, no. 3. 